\title{
Prosodic Features of East Acehnese Dialect Based on Age Factor: An Experimental Phonetic Study
}

\author{
Rohani Ganie $^{1}$, T. Syarfina ${ }^{2}$, T. Silvana Sinar ${ }^{3}$ \\ (Universitas Sumatera Utara, Medan) \\ (Universitas Sumatera Utara, Medan) \\ (Universitas Sumatera Utara, Medan)
}

\begin{abstract}
This study analyzed the prosodic features of East Acehnese dialect speech act, based on age factor of the speaker through Acoustic Phonetic Theory by using Praat Program. The target of this study was the directive speech in the form of command and offer. The findings of this study is that the speech tone of directive speech kapurono seudati ke jih based on basic tone, final tone, high tone, low tone, and temporal duration, uttered by the teenage informant is higher than that uttered by the adult informant. On the contrary, the speech tone of directive sentence tagun keumamah ke lon siat based on basic tone, final tone, low tone, and temporal duration, uttered by the adult informant is higher than that uttered by the teenage informant. Only in high tone, the speech tone uttered by the adult informant is lower than that uttered by the teenage informant. The duration of utterance uttered by teenage informant is longer than that uttered by the adult informant.
\end{abstract}

Keywords: Acehnese, accoustic phonetics, directive speech, duration prosodic features

\section{Introduction}

Language functions as a means of communication or interaction owned by human beings. Language tends to experience changed in line with the the change occurs in the community of its speakers. As we know, language has been made expression and communication facilities in the human life activity such as in the fields of culture, science and technology. In general, language functions as a means of communication between community members.

Language is found anywhere. In the life of normal human beings, language is inseparable. Language can penetrate into human's thought, can bridge the relationship between one man to another, can even penerate into human' dream. Thus, language is very important in human life because language control human's way of thinking and action.

Speech act is to do certain act through the words spoken by human beings to communicate feeling, thought, or desire for example in begging for something, refusing (command and offer), expressing gratitude, greeting, praising, apologizing, and complaining. When speaking, the speaker not only speaks but also acts or intends to do something such as praising, entertaining, criticizing, stating or informing something. Even ordering or asking the speaker for doing something for himself/herself in accordance with the intention expressed through what he/she said (Austin, 1962).

The conversation in communication is always contextual and each utterance must be based on the context. This influences the utterance in producing statement when communicating. Being contextual, the utterance produced determines the intonation used. Different speaker will use different intonation in communication including when uttering directive speech act.

Based on the opinions of the linguists above, it can be concluded that all languages existing in the world have their own speech act standard including East Acehnese dialect. As community, in communicating, the people of Aceh cannot be separated from the speech act as explained by the linguists above. In communicating, Aceh community is always bound to their eastern culture which is full of courtesy, empathy, tolerance, respecting status, age, and so forth.

The local language, is still used as a means of communication and interaction in its own community. There are nine existing languages that are still used by Aceh community to communicate in the Province of Nanggroe Aceh Darussalam such as the languages of Acehnese, Gayo, Tamiang, Aneuk Jamee, Kluet, Singkil, Simeulu and Haloban.

In these two decades, there are very limited studies on Acehnese. Some previous researchers were conducted by M. Adnan Hanafiah and Ibrahim Makam (1976) Acehnese Structure; Zaini Ali et al (1983) Morphological System of Acehnese Verb and (1984) Repetition System of Acehnese; Budiman Sulaiman et al (1983) Acehnese Structure: Morphology dan Syntax; Isda Pramuniati (2009) Speech Act Strategy and Pragmatic Sensitivity of Melarang (Prohibiting) in North Acehnese Dialect; Rohani Ganie (2008) Genre Analysis Genre in Hikayat Perang Sabil (The Story of Sabil War): Systemic Functional Linguistics Approach; and Ridwan 
Hanafiah (2011) The Choice and Attitude of Language in Political Communication by Local Political Parties in Aceh Government; Halliday (2004) who originated systemic functional grammar said that there are four kinds of speech function, they are statement, question, command and offer.

The description above shows that study on intonation of Acehnese speech act based on the factor of speakers' age, especially the one related to experimental phonetics, up to now, has not yet been conducted. Therefore, the purpose of this study was to prove that the speakers' age produces different intonation. With the acquisition of the intonation, this study was to discuss the politeness intonation of speech act in order and request in the Acehnese is Dialect based on the difference of speakers' age.

\section{Acoustic Phonetics}

Based on the process of the language sound formation, phonetics can be distinguished into three types such as articulatory phonetics, auditory phonetics, and acoustic phonetics. Articulatory phonetics is about how language sound is produced by the speaker. A phonetician will be interested in the event of sound formation or air fibration, the movement of articulators, and the coordination of the articulators in creating a sound. Auditory phonetics is about how the sound is received by the ears of speaker. This field does not talk about how the ears work or the mechanism of nerve system between the ears and brain, but about hearing sensation which is the activity of the brain itself, special attention is focused on the reaction of listener to the specific physical stimulation he/she knows which is done to his/her ears.

Acoustic phonetics studies sound waves as a physical event or natural phenomenon forming the relationship between the speaker and the listener. The essence of this field is the acoustic physical concept and engineering; but the study on acoustic phonetics also integrates the science about how the signal of statement is produced by the speaker, how the signals are perceived by the listener, and how the signals are structured by language phonology.

Based on the above explanation, this intonation study starting from acoustic phonetics, includes two phonetic elements such as production and acoustic. What is meant by production stage is the utterance as the result pf production used as phonetic data. Acoustic stage is the stage of data processing related to the analysis of acoustic characteristics found in the utterances studied.

\subsection{Frequency}

Sound frequency the high and low tone of a sound. In other words, sound frequency, according to Lehiste, is the number of vibrations in one second (Lehiste, 1970:61). Frequency determines tone. It is very difficult to concretely describe about sound because sound can be uttered but cannot be measured. Physically, sound can be measured and described in the form of graphic called sinusoidal graphic. Hayward (2000:26) argued that the important thing in sinusiodal wave (sine waves) is that the wave is repaeting that it can be described as cycle.

Intonation involves the incident of repeating tone pattern used for a group of meaning, either in single word or varied phrase. The variation of basic frequency during the utterance forms a pitch range. In line with that, ' $t$ Hart, Collier, and Cohen (1990:10) argued that intonation is a group or sequence of tone in utterance. This study of EAD directive utterance intonation is based on the definition defined by 't Hart, Collier, and Cohen.

\subsection{Duration}

Duration can be defined as time span of articulatory series and time dimension of acoustic signal. According to Sugiono (2003), duration is a time span needed to realize a sound segment measured in milisecond unit. If the segment is in the form of sentence, the time span is called tempo. Van Heuven (1994) argued that temporal structure also known as duration is a set of rules determining the pattern of duration in utterance.

At phonetic level, tone is a set of tones in the form of pitch level, pitch volume, and pitch quality. Pitch movement is the composition of relevant tones in the domination of utterance-forming constituent. In the study conducted by Halim (1974:106), this concept of pitch movement is about the same as the concept of pitch pattern. Pitch contour is a pitch combination providing melodic characteristic of an utterance in the domination of sentence or forming the melodic structure of an utterance. In several approaches, intonation was analyzed as a contour containing varied pitch levels. In this study, pitch contour, from now on it is only called contour, is more combination of pitch movement rather than tone (pitch).

This study employed the experimental phonetics which is established based on the foundation of impressionistic phonetics. Experimental phonetics, as commonly used term, involves various investigation of utterance through instrument. The instrument is used to visualize several aspects of utterance event and also to provide the basic of measurement. But, for example, cassette recording used to listen repeatedly is not included in the coverage of experimental phonetics. If the cassette recording is installed into computer and used to produced an acoustic analysis of the activity will be described as an experimental investigation (Hayward, 2000). The ability to visually present the sound and describe it objectively in a way independent from human sensoric perception, is a main thing for modern experimental phonetics. 


\section{Method}

\subsection{Source of Data}

The source of data for this study is the sentence of directive speech act such as command sentence with its target sentence is Kapurono seudati ke jih and order sentence of tagun keumamah ke lon siat narrated by 2 informants - adult and teenage categories.

\subsection{Data Collecting and Processing}

The data were collected through recording the narration of EAD in an command sentence of Kapurono seudati ke jih "Teach him/her seudati dance", and the order of tagun keumamah ke lon siat. The informants were given a condition in the form of dialogue, then the informant was asked to realize a narration of the sentence of directive speech act. The data were recorded by using an audio recorder equipped with head set mic and then the data were digitalized through computer program.

The data obtained, the sound recorded from the voice of the informants were digitalized and analyzed through computer with Praat program. This program was used by the very latest researchers in the field of experimental phonetics such as Remijsen (2002), Sugiyono (2003), Rahyono (2003), Stoel (2004), and Syarfina T. (2008). Data procesing was done in several stages such as digitalization, data segmentation, copying contour, and statistic tests.

On the stage of digitalization, the data as recorded with audio cassette and then transferred to the digital format - in the form of sound wave - followed by choosing the utterances to be analyzed, The data chosen or extracted are the data cleaned from the parts which are not needed and innaccordance with the original voice of the respondents then the clean data were coded.

The next step is data segmentation that is breaking the selected data into single segment, sound per sound and data marking limited by unbit of analysis. Each segment is labelled with common phonetic symbol. This step is done to prepare the next measurement either frequency, duration or intensity measurement.

\subsection{Data Analysis}

After the data were collected, the data were analyzed through computer using Praat program version 4.0.2.7. The process of analysis was conducted in detail in several stages as follows: (1) process of digitalization, and (2) measuring acoustic characteristics in terms of measuring frequency and duration of each utterance.

The data obtained from the result of recording were extracted to be analyzed (in WAV format). After that, word segmentation was done (Text Grid), pitch and intonation manipulation (manipulation), and the extraction of the result of manipulation (Pitch Tier). In data manipulation, this study used IPO $^{2}$ (Instituut voor Perceptie Onderzook). The result of the data together with Text Grid was copied into PRATT Picture and moved to Microsoft Word (MW) and then the pitch contour and duration were copied.

Halliday (2004) who originated systemic functional grammar said that there are four kinds of speech functions, they are statement, question, command and offer. This study was focused on the function of directive sentence (command) and request sentence (offer).

\section{Discussion}

\subsection{Prosody in Directive Sentence \\ 4.1.1 Primary Contour}

Four target sentences are functioned as the base in giving pitch contour and sentence making which have been distillated. The four sentences are selected based on the age of speakers, two contours are uttered by adult speakers and the other two contours are uttered by teenage speakers. The four corpus of sentence data chosen in this study are among other things: 
1). Target sentence of command utterance kapurono seudati ke jih uttered by adult female:

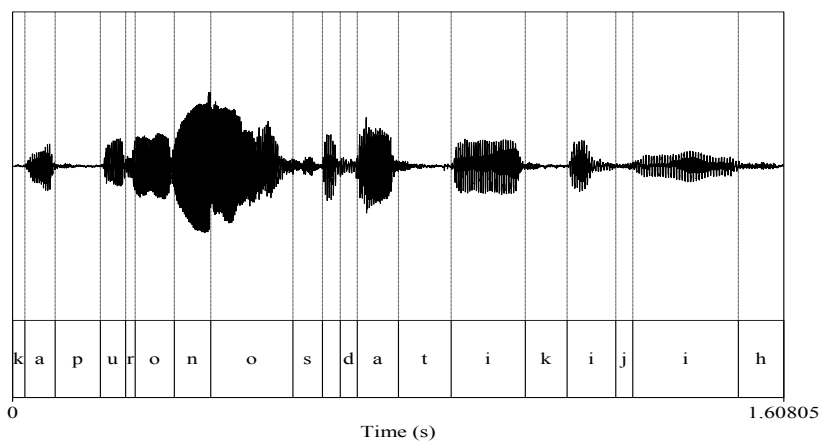

Figure 1. Acoustic Signal and Text Grid of Command Utterance Kapurono seudati ke jih uttered by adult female

2) Target sentence of order sentence utterance tagun keumamah ke lon siat uttered by adult female:

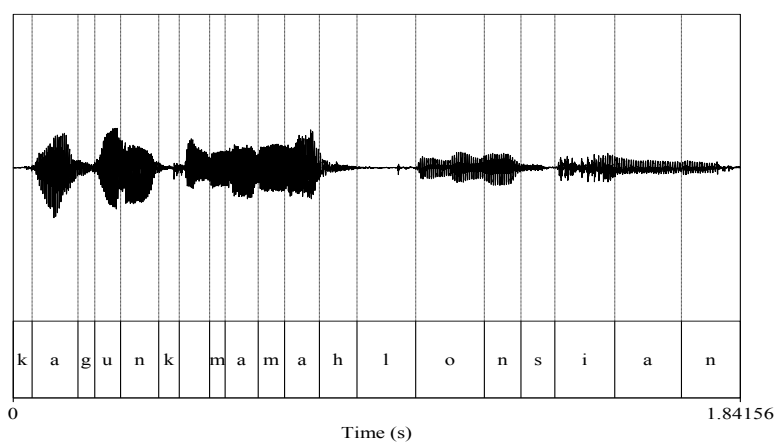

Figure 2. Oscillogram of Acoustic Signal and Text Grid of Order Directive Utterance tagun keumamah ke lon siat uttered by adult female

3) Primary corpus of directive sentence utterance kapurono seudati ke jih uttered by teenage female:

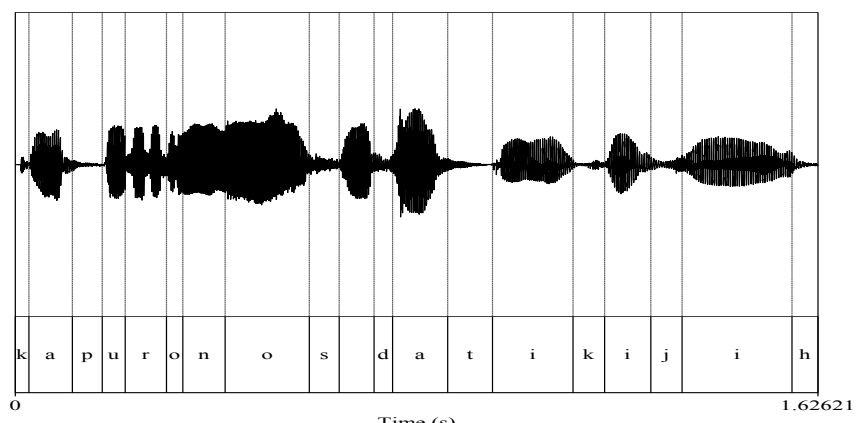

Figure 3. Oscillogram of Acoustic Signal and Text Grid of Directive Utterance Kapurono seudati ke jih uttered by teenage female

4) Data corpus of request sentence utterance tagun keumamah ke lon siat uttered by teenage female:

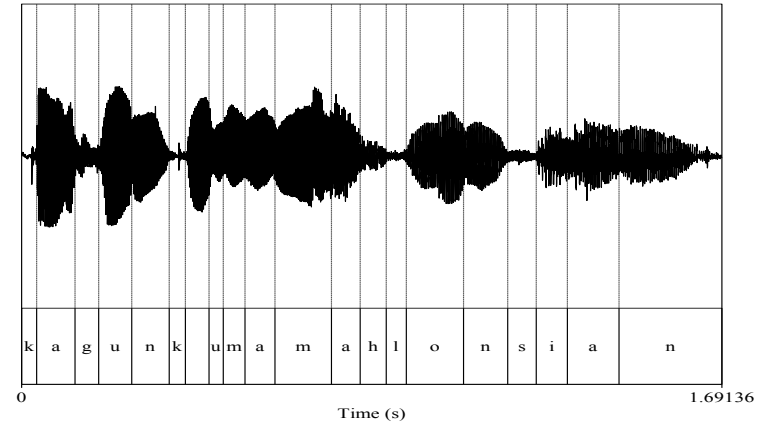

Figure 4. Oscillogram of Acoustic Signal and Text Grid of Request Directive Utterance tagun keumamah ke lon siat uttered by adult female 


\subsection{Pitch Movement of Directive Speech}

In this part, the description of pitch movement in the primary contour of command utterance kapurono seudati ke jih and order utterance tagun keumamah ke lon siat is discussed. This discussion is important with the reason that pitch movement commonly called local attributes is the element establishing pitch structure (pitch contour) or commonly called global attributes. The determination of pitch movement is described based on the segmentation of sound syllable at the level of word and phrase in utterance. This is done in order to obtain a full and more detailed description of pitch contour in the utterance to be analyzed. In other words, in syllabel analysis, the detected pitch movement is more detailed, especially about the ups and downs of the pitch movement. For example, the pitch movement analysis of the phrase of kapurono, if seen from the contour of the command utterance kapurono seudati ke jih, the only thing seen is that pitch movement raises.

\subsubsection{Pitch Movement of kapurono}

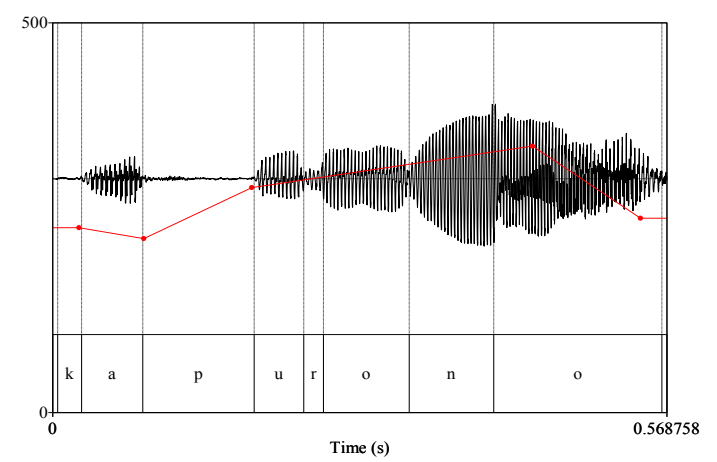

Figure 5. Pitch Movement of kapurono: Adult Speaker

Pitch Movement of kapurono in the primary contour of command kapurono seudati ke jih uttered by adult speakers consists of 4 (four) pitch movements. First, the pitch movement falls at $k a$ syllable. Pitch position at $237.2 \mathrm{~Hz}$ falls to pitch position at $223.1 \mathrm{~Hz}$. Second, the pitch movement raises at $p u$ syllable. The pitch position at $223.1 \mathrm{~Hz}$ raises to the pitch position $300.1 \mathrm{~Hz}$. Third, the pitch movement raises at ro syllable. The pitch position at $300.1 \mathrm{~Hz}$ raises to the pitch position at $322.8 \mathrm{~Hz}$. Fourth, the pitch movement goes up and down at no syllable. The pitch position at $332.8 \mathrm{~Hz}$ raises to the pitch position at $342 \mathrm{~Hz}$ then goes down to the pitch position at $294.4 \mathrm{~Hz}$. The conclusion is that the pitch movement of kapurono in the primary contour of command utterance kapurono seudati ke jih uttered by adult speakers is an up and down pitch movement with the inclination pitch contour.

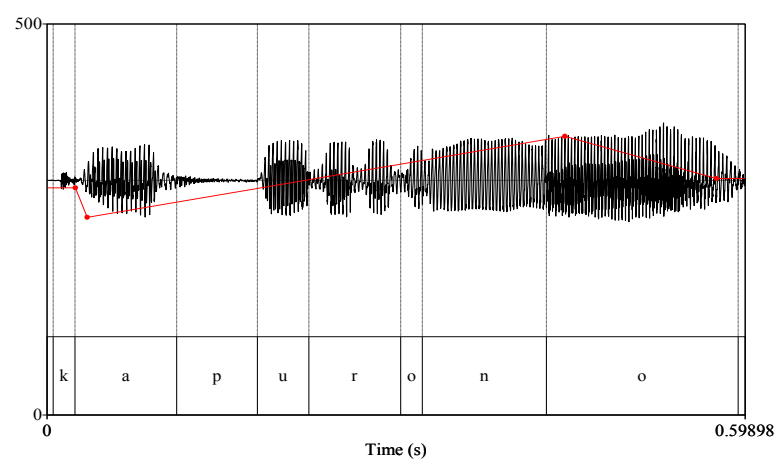

Figure 6. Pitch Movement of kapurono: Teenage Speaker

The pitch movement of kapurono in the primary contour of command kapurono seudati ke jih uttered by teenage speakers consists of 4 (four) pitch movements. First, the pitch movement goes up and down at $k a$ syllable. The pitch position at $290.4 \mathrm{~Hz}$ falls to the pitch position at $252.6 \mathrm{~Hz}$ and raises to the pitch position at $269.2 \mathrm{~Hz}$. Second, the pitch movement raises at $p u$ syllable. The pitch position at $269.2 \mathrm{~Hz}$ raises to the pitch position $302.2 \mathrm{~Hz}$. Third, the pitch movement raises at ro syllable. The pitch position at $302.2 \mathrm{~Hz}$ raises to the pitch position at $353.8 \mathrm{~Hz}$. Fourth, the pitch movement goes up and down at no syllable. The pitch position at $353.8 \mathrm{~Hz}$ raises to the pitch position at $356.5 \mathrm{~Hz}$ then goes down to the pitch position at $302.5 \mathrm{~Hz}$. The conclusion is that the pitch movement of kapurono in the primary contour of command utterance kapurono 
seudati ke jih uttered by teenage speakers is an up and down pitch movement with the inclination pitch contour. Then, the pitch movement of kapurono in the primary contour of directive sentence utterance kapurono seudati $k e$ jih uttered by both teenage and adult speakers do not show any difference. Both pitch movements shows a relatively similar contour - the pitch movement goes and down with inclination contour.

\subsubsection{Pitch Movement of seudati}

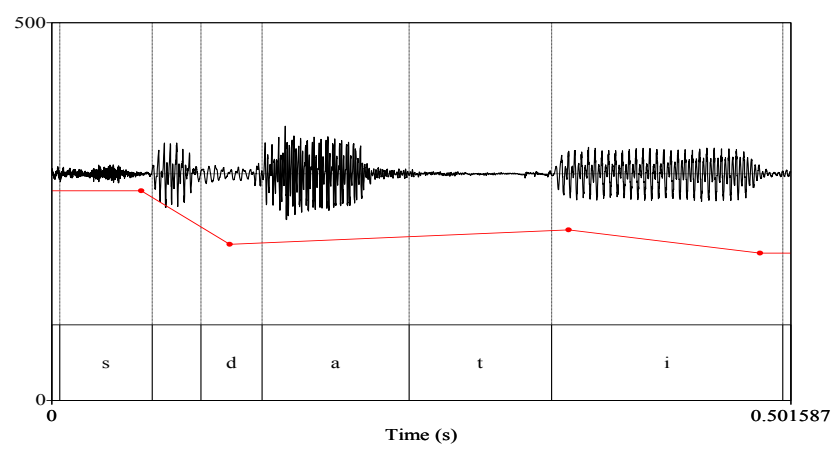

Figure 7. Pitch Movement of seudati: Adult Speaker

Pitch Movement of seudati in the primary contour of command kapurono seudati ke jih uttered by adult speakers consists of 3 (three) pitch movements. First, the pitch movement falls at seu syllable. Pitch position at $277.4 \mathrm{~Hz}$ falls to pitch position at $232.0 \mathrm{~Hz}$. Second, the pitch movement goes up and down at da syllable. The pitch position at $232.0 \mathrm{~Hz}$ falls to the pitch position at $206.6 \mathrm{~Hz}$ then goes up to the pitch position at $217.6 \mathrm{~Hz}$. Third, the pitch movement goes up and down at ti syllable. The pitch position at $217.6 \mathrm{~Hz}$ raises to the pitch position at $225.7 \mathrm{~Hz}$ then goes down to the pitch position at $192.5 \mathrm{~Hz}$. The conclusion is that the pitch movement of seudati in the primary contour of command utterance kapurono seudati ke jih uttered by adult speakers is a falling pitch movement with the declination pitch contour.

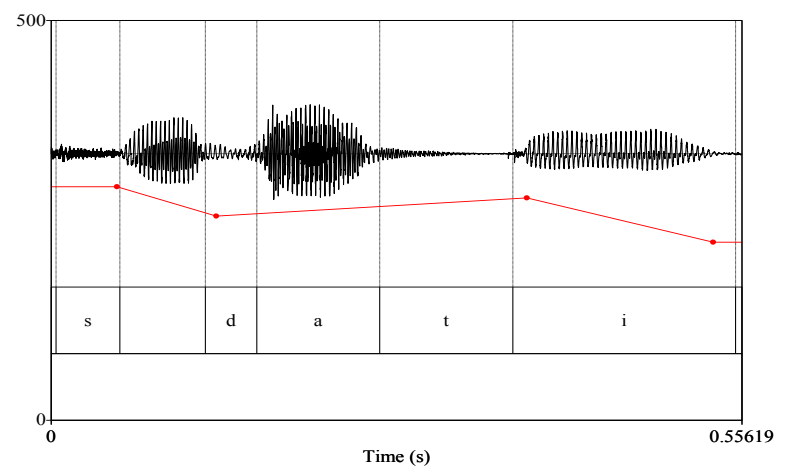

Figure 8. Pitch Movement of seudati: Teenage Speaker

Pitch Movement of seudati in the primary contour of command kapurono seudati ke jih uttered by teenage speakers consists of 3 (three) pitch movements. First, the pitch movement falls at seu syllable. Pitch position at $292.0 \mathrm{~Hz}$ falls to pitch position at $260.0 \mathrm{~Hz}$. Second, the pitch movement goes up and down at $d a$ syllable. The pitch position at $260.0 \mathrm{~Hz}$ falls to the pitch position at $255.4 \mathrm{~Hz}$ then goes up to the pitch position at $267.1 \mathrm{~Hz}$. Third, the pitch movement goes up and down at $t i$ syllable. The pitch position at $267.1 \mathrm{~Hz}$ raises to the pitch position at $278.1 \mathrm{~Hz}$ then goes down to the pitch position at $222.6 \mathrm{~Hz}$. The conclusion is that the pitch movement of seudati in the primary contour of command utterance kapurono seudati ke jih uttered by teenage speakers is a falling pitch movement with the declination pitch contour. 


\subsubsection{Pitch Movement of ke jih}

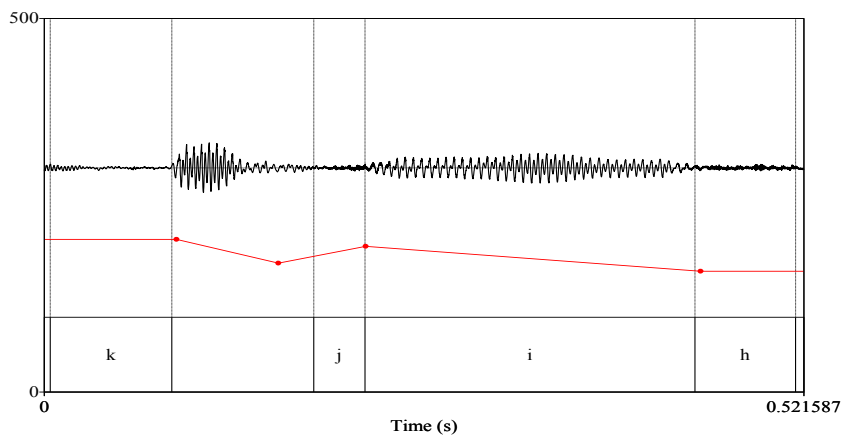

Figure 9. Pitch Movement of ke jih: Adult Speaker

Pitch Movement of ke jih in the primary contour of command kapurono seudati ke jih uttered by adult speakers consists of 2 (two) pitch movements. First, the pitch movement goes up and down at ke syllable. The pitch position at $204.4 \mathrm{~Hz}$ falls to the pitch position at $172.5 \mathrm{~Hz}$ then goes up to the pitch position at $182.5 \mathrm{~Hz}$. Second, the pitch movement goes up and down at jih syllable. The pitch position at $182.5 \mathrm{~Hz}$ raises to the pitch position at $195.0 \mathrm{~Hz}$ then goes down to the pitch position at $161.7 \mathrm{~Hz}$. The conclusion is that the pitch movement of ke jih in the primary contour of command utterance kapurono seudati ke jih uttered by adult speakers is a falling pitch movement with the declination pitch contour.

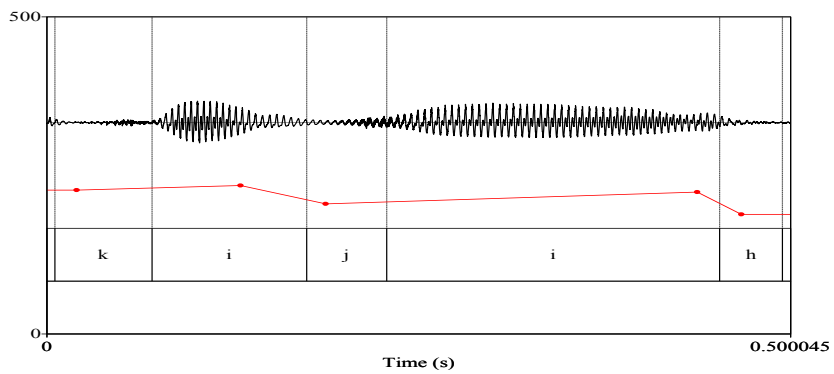

Figure 10. Pitch Movement of ke jih: Teenage Speaker

Pitch Movement of ke jih in the primary contour of command kapurono seudati ke jih uttered by teenage speakers consists of 2 (two) pitch movements. First, the pitch movement goes up and down at ke syllable. The pitch position at $226.8 \mathrm{~Hz}$ raises to the pitch position at $234.1 \mathrm{~Hz}$ then goes down to the pitch position at 205.2 Hz. Second, the pitch movement goes up and down at jih syllable. The pitch position at $205.2 \mathrm{~Hz}$ raises to the pitch position at $223.8 \mathrm{~Hz}$ then goes down to the pitch position at $188.7 \mathrm{~Hz}$. The conclusion is that the pitch movement of ke jih in the primary contour of command utterance kapurono seudati ke jih uttered by teenage speakers is a falling pitch movement with the declination pitch contour.

\subsubsection{Pitch Movement of tagun}

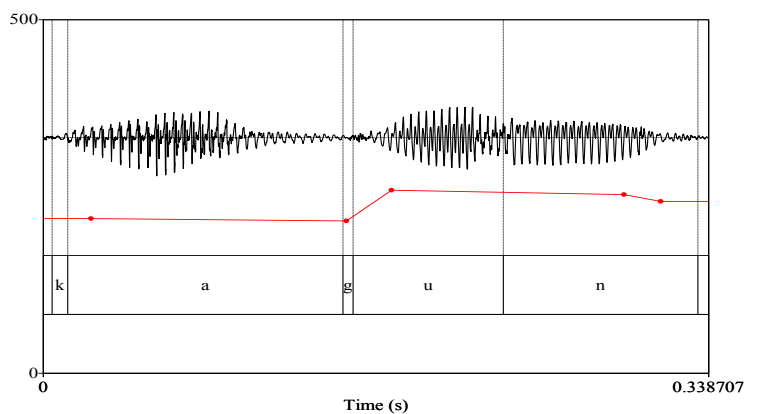

Figure 11. Pitch Movement of tagun: Adult Speaker 
Pitch Movement of tagun in the primary contour of order tagun keumamah ke lon siat uttered by adult speakers consists of 2 (two) pitch movements. First, the pitch movement goes down at $t a$ syllable. The pitch position at $218.9 \mathrm{~Hz}$ falls to the pitch position at $215.5 \mathrm{~Hz}$. Second, the pitch movement goes up and down at gun syllable. The pitch position at $215.5 \mathrm{~Hz}$ raises to the pitch position at $258.8 \mathrm{~Hz}$ then goes down to the pitch position at $243.1 \mathrm{~Hz}$. The conclusion is that the pitch movement of tagun in the primary contour of order utterance tagun keumamah ke lon siat uttered by adult speakers shows the inclination contour.

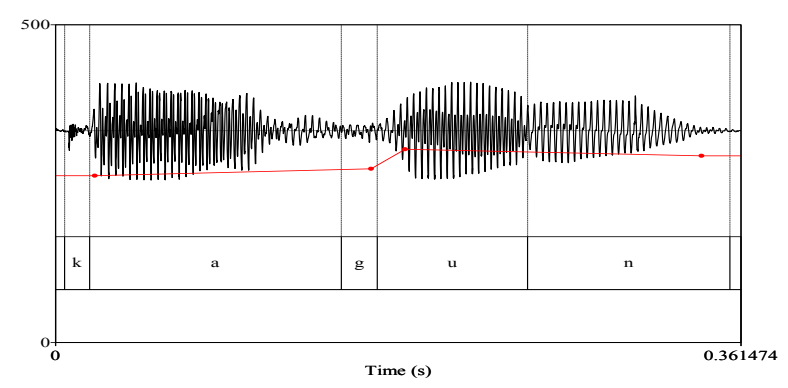

Figure 12. Pitch Movement of tagun: Teenage Speaker

Pitch Movement of tagun in the primary contour of order kapurono seudati ke jih uttered by teenage speakers consists of 2 (two) pitch movements. First, the pitch movement goes up at $t a$ syllable. The pitch position at $262.6 \mathrm{~Hz}$ raises to the pitch position at $273.3 \mathrm{~Hz}$. Second, the pitch movement goes up and down at gun syllable. The pitch position at $273.3 \mathrm{~Hz}$ raises to the pitch position at $304.2 \mathrm{~Hz}$ then goes down to the pitch position at $293.8 \mathrm{~Hz}$. The conclusion is that the pitch movement of tagun in the primary contour of order utterance tagun keumamah ke lon siat uttered by teenage speakers shows the inclination contour.

The difference of pitch movement of tagun in the primary contour of order tagun keumamah ke lon siat uttered by adult and teenage speakers is in the first pitch movement at $t a$ syllable. Adult speakers uttered it in a falling pitch movement while the teenage speakers uttered it in a raising pitch movement.

\subsubsection{Pitch Movement of keumamah}

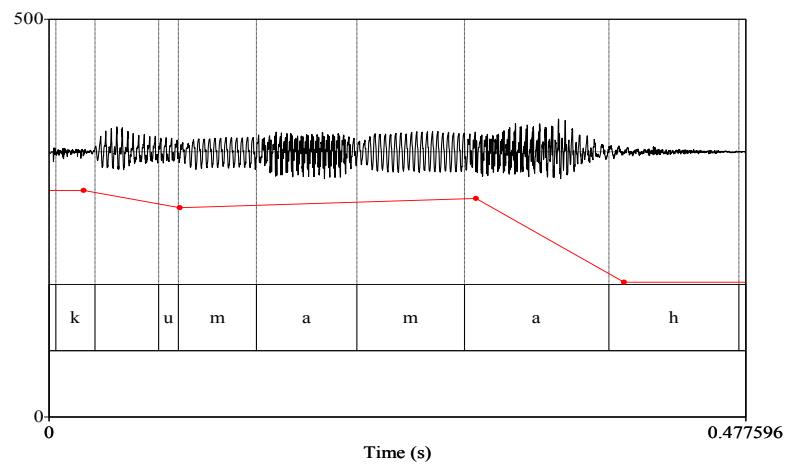

Figure 13. Pitch Movement of keumamah: Adult Speaker

Pitch Movement of keumamah in the primary contour of order tagun keumamah ke lon siat uttered by adult speakers consists of 3 (three) pitch movements. First, the pitch movement goes down at keu syllable. The pitch position at $284.9 \mathrm{~Hz}$ falls to the pitch position at $263.0 \mathrm{~Hz}$. Second, the pitch movement goes up at $m a$ syllable. The pitch position at $263.0 \mathrm{~Hz}$ raises to the pitch position at $269.2 \mathrm{~Hz}$. Third, the pitch position raises at mah syllable. The pitch position at $269.2 \mathrm{~Hz}$ raises to the pitch position at $274.8 \mathrm{~Hz}$ then goes down to the pitch position at $169.4 \mathrm{~Hz}$. The conclusion is that the pitch movement of keumamah in the primary contour of order utterance tagun keumamah ke lon siat uttered by adult speakers shows the declination pitch contour. 


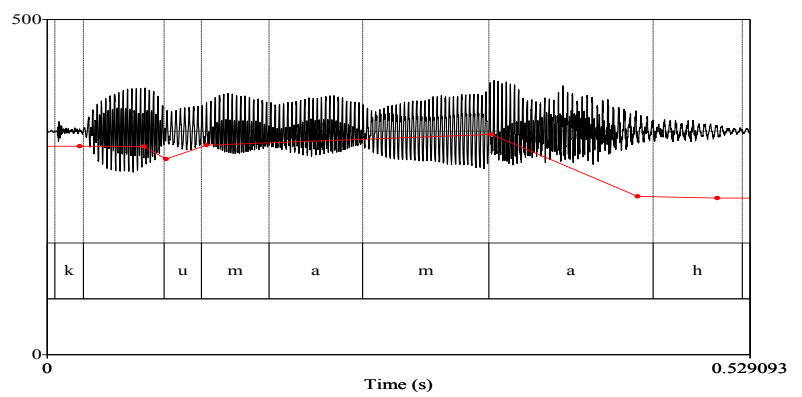

Figure 14. Pitch Movement of keumamah: Teenage Speaker

Pitch Movement of keumamah in the primary contour of order tagun keumamah ke lon siat uttered by teenage speakers consists of 3 (three) pitch movements. First, the pitch movement goes up and down at keu syllable. The pitch position at $310.9 \mathrm{~Hz}$ falls to the pitch position at $291.9 \mathrm{~Hz}$ then raises to the pitch position at $322.8 \mathrm{~Hz}$. Second, the pitch movement goes up at $m a$ syllable. The pitch position at $312.5 \mathrm{~Hz}$ raises to the pitch position at $322.8 \mathrm{~Hz}$. Third, the pitch movement goes up and down at mah syllable. The pitch position at 322.8 to the pitch position at $328.5 \mathrm{~Hz}$ then goes down to the pitch position at $233.5 \mathrm{~Hz}$. The conclusion is that the pitch movement of keumamah in the primary contour of order utterance tagun keumamah ke lon siat uttered by teenage speakers shows the declination pitch contour.

The difference of pitch movement of keumamah in the primary contour of order tagun keumamah ke lon siat uttered by adult and teenage speakers is in the first pitch movement at keu syllable. Adult speakers uttered it in a falling pitch movement while the teenage speakers uttered it in an up and down pitch movement. But, if viewed from the pitch contour of keumamah in the primary contour of order tagun keumamah ke lon siat uttered by adult and teenage speakers, we cannot see any difference because both of them have the declination pitch contour.

\subsubsection{Pitch Movement of $k e$ lon}

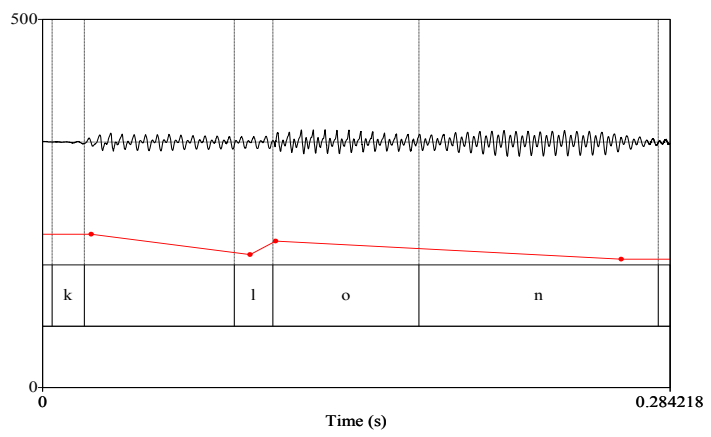

Figure 15. Pitch Movement of ke lon: Adult Speaker

Pitch Movement of ke lon in the primary contour of order tagun keumamah ke lon siat uttered by adult speakers consists of 2 (two) pitch movements. First, the pitch movement goes down at ke syllable. The pitch position at $208.2 \mathrm{~Hz}$ falls to the pitch position at $180.4 \mathrm{~Hz}$. Second, the pitch movement goes up and down at lon syllable. The pitch position at $180.4 \mathrm{~Hz}$ raises to the pitch position at $199.0 \mathrm{~Hz}$ then goes down to the pitch position at $174.3 \mathrm{~Hz}$. The conclusion is that the pitch movement of ke lon in the primary contour of order utterance tagun keumamah ke lon siat uttered by adult speakers shows a falling pitch movement with declination pitch contour. 


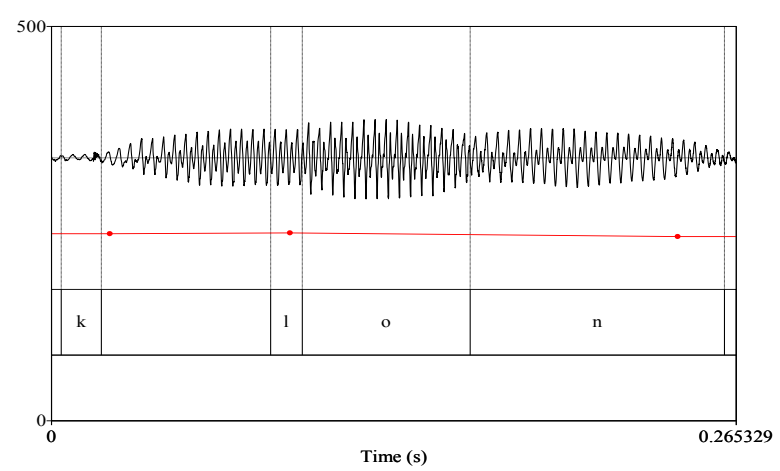

Figure 16. Pitch Movement of ke lon: Teenage Speaker

Pitch Movement of ke lon in the primary contour of order tagun keumamah ke lon siat uttered by teenage speakers consists of 2 (two) pitch movements. First, the pitch movement goes up at $k e$ syllable. The pitch position at $237.1 \mathrm{~Hz}$ raises to the pitch position at $238.1 \mathrm{~Hz}$. Second, the pitch movement goes up and down at lon syllable. The pitch position at $238.1 \mathrm{~Hz}$ falls to the pitch position at $233.6 \mathrm{~Hz}$. The conclusion is that the pitch movement of ke lon in the primary contour of order utterance tagun keumamah ke lon siat uttered by teenage speakers shows a falling pitch movement with the relatively flat pitch contour.

The difference of pitch movement of ke lon in the primary contour of order tagun keumamah ke lon siat uttered by adult and teenage speakers is in the first pitch movement at $k e$ syllable. Adult speakers uttered it in a falling pitch movement while the teenage speakers uttered it in a raising pitch movement.

\subsubsection{Pitch Movement of siat}

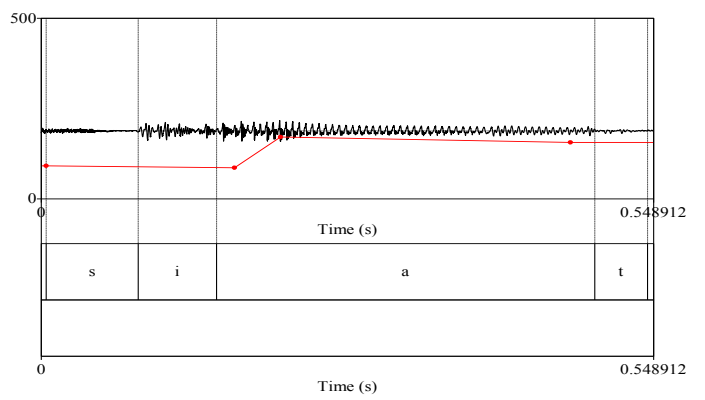

Figure 17. Pitch Movement of siat: Adult Speaker

Pitch Movement of siat in the primary contour of order tagun keumamah ke lon siat uttered by adult speakers consists of 2 (two) pitch movements. First, the pitch movement goes down at si syllable. The pitch position at $174.3 \mathrm{~Hz}$ falls to the pitch position at $86.4 \mathrm{~Hz}$. Second, the pitch movement goes up and down at at syllable. The pitch position at $86.4 \mathrm{~Hz}$ raises to the pitch position at $171.4 \mathrm{~Hz}$ then goes down to the pitch position at $156.2 \mathrm{~Hz}$. The conclusion is that the pitch movement of siat in the primary contour of order utterance tagun keumamah ke lon siat uttered by adult speakers shows a raising pitch movement with inclination pitch contour.

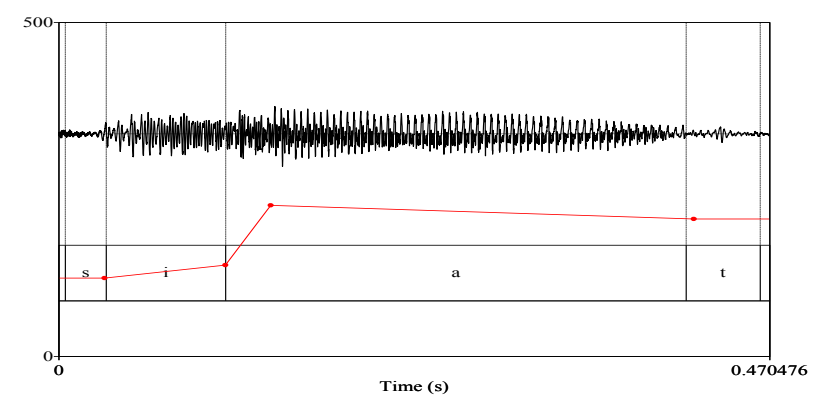

Figure 18. Pitch Movement of siat: Teenage Speaker

Pitch Movement of siat in the primary contour of order tagun keumamah ke lon siat uttered by teenage speakers consists of 2 (two) pitch movements. First, the pitch movement goes up at si syllable. The pitch 
position at $117.4 \mathrm{~Hz}$ raises to the pitch position at $136.8 \mathrm{~Hz}$. Second, the pitch movement goes up and down at at syllable. The pitch position at $136.8 \mathrm{~Hz}$ raises to the pitch position at $226.4 \mathrm{~Hz}$ then falls to the pitch position at $205.8 \mathrm{~Hz}$. The conclusion is that the pitch movement of siat in the primary contour of order utterance tagun keumamah ke lon siat uttered by teenage speakers shows a raising pitch movement with inclination pitch contour.

The difference of pitch movement of siat in the primary contour of order tagun keumamah ke lon siat uttered by adult and teenage speakers is in the first pitch movement at kesyllable. Adult speakers uttered it in a falling pitch movement while the teenage speakers uttered it in a raising pitch movement.

\section{Conclusion}

As the result of this study which is to prove that the age of speakers produces different prosodic, the conclusion drawn is as follows:

The frequency of command utterance by teenagers and adults. The frequency of each utterance is measured based on basic frequency, final frequency, high frequency, and low frequency.

The frequency of command utterance kapurono seudati ke jih uttered by female teenagers with basic frequency $(254.1 \mathrm{~Hz})$, final frequency $(207.4 \mathrm{~Hz})$, high frequency $(356.5 \mathrm{~Hz})$, low frequency $(202.5 \mathrm{~Hz})$ and temporal duration (1.6262 seconds), while the one uttered by female adults are with basic frequency $(229.7 \mathrm{~Hz})$, final frequency $(161.6 \mathrm{~Hz})$, high frequency $(346.9 \mathrm{~Hz})$, low frequency $(161.6 \mathrm{~Hz})$ and temporal duration $(1.6080$ seconds). It can be concluded that the frequency of the utterance uttered by female teenagers is bigger than that uttered by female adults.

The frequency of offer utterance tagun keumamah ke lon siat uttered by female teenagers with basic frequency $(263.1 \mathrm{~Hz})$, final frequency $(205.5 \mathrm{~Hz})$, high frequency $(329.1 \mathrm{~Hz})$, low frequency $(205.5 \mathrm{~Hz})$ and temporal duration (1.6913 seconds), while the one uttered by female adults are with basic frequency $(241.4 \mathrm{~Hz})$, final frequency $(161.1 \mathrm{~Hz})$, high frequency $(286.5 \mathrm{~Hz})$, low frequency $(161.1 \mathrm{~Hz})$ and temporal duration $(1.8415$ seconds). The frequency of the utterance uttered by female teenagers is bigger than that uttered by female adults. Therefore, the command utterance kapurono seudati ke jih and offer utterance tagun keumamah ke lon siat uttered by female adults is more lower than that uttered by female teenagers.

If the command utterance kapurono seudati ke jih uttered by female speakers is compared with that uttered by adult speakers that the duration of the utterance uttered by female teenagers is longer than that uttered by female adult speakers.

If offer utterance tagun keumamah ke lon siat uttered by female speakers is compared with that uttered by adult speakers, that the duration of the utterance uttered by adult speakers is longer than that uttered by teenage speakers.

In general, in the utterance of command and offer, the frequency of utterance uttered by teenager is higher than that uttered by adult speakers. The duration of utterance uttered by teenager is longer than that uttered by adult speakers. This occurs because the articulators of adult become naturally weak that there is a change in the adult's vocal cords.

\section{References}

[1] J.L. Austin, How to do things with words (Oxford: Clarendon Press, 1962).

[2] Ibrahim Makam and M. Adnan Hanafiah, Struktur bahasa Aceh (Jakarta: Pusat Pembinaan dan Pengembangan Bahasa Departemen Pendidikan dan Kebudayaan, 1984).

[3] Zaini Ali, Sistem morfologi kata kerja bahasa Aceh (Jakarta: Pusat Pembinaan dan Pengembangan Bahasa Departemen Pendidikan dan Kebudayaan,1983)

[4] Budiman Sulaiman, Struktur bahasa Aceh: morfologi dan sintaksis (Jakarta: Pusat Pembinaan dan Pengembangan Bahasa Departemen Pendidikan dan Kebudayaan, 1983).

[5] Isda Pramuniati, Strategi tindak tutur dan kepekaan pragmatik melarang dalam bahasa Aceh dialek Aceh utara, doctoral dissertation, SPS Linguistik USU, Medan, 2009.

[6] Ridwan Hanafiah, Pemilihan bahasa dan sikap bahasa dalam komunikasi politik oleh partai politik lokal di pemerintahan Aceh, doctoral dissertation, SPS Linguistik USU, Medan, 2011.

[7] M.A.K. Halliday, An introduction to functional grammar, 3d ed (London: Arnold, 2004).

[8] Ilse Lehiste, Suprasegmentals (Cambridge: The MIT Press, 1970).

[9] Katrina Hayward, Experimental phonetics (London: Pearson Education Limited, 2000).

[10] J.'t Hart, R. Collier, and A. Cohen, A perceptual study of intonation: an experimental-phonetic approach to speech melody (New York: Cambride University Press, 1990).

[11] Sugiyono, Pemarkah prosodik kontras deklaratif dan interogatif bahasa Melayu Kutai, doctoral dissertation, Pascasarjana UI, Depok, 2003.

[12] Vincent J. Van Heuven, Introducing prosodic phonetics (Leiden: University of Leiden, 1994).

[13] Amran Halim, Intonation in relation to syntax in bahasa Indonesia (Jakarta: Djambatan, 1969).

[14] Bert Remijsen, Word-prosodic systems of Raja Ampat languages, doctoral dissertation, Leiden University - LOT Dissertation Series vol. 49, 2002 .

[15] F.X. Rahyono, The politeness prosody of the Javanese directive speech, Wacana: Jurnal Ilmu Pengetahuan Budaya, 2 (2), 2009, $258-278$.

[16] Ruben Stoel, Gradient Perception of Intonation (University of Postdam, 2004).

[17] T. Syarfina, Ciri akustik sebagai pemarkah sosial penutur bahasa Melayu Deli, doctoral dissertation, SPS Linguistik USU, Medan, 2008. 